\title{
VAV2 wt Allele
}

National Cancer Institute

\section{Source}

National Cancer Institute. VAV2 wt Allele. NCI Thesaurus. Code C52960.

Human VAV2 wild type allele is located in the vicinity of $9 q 34.1$ and is approximately 231

$\mathrm{kb}$ in leng th. This allele, which encodes guanine nucleotide exchange factor VAV2 protein, is involved in the regulation of cytoskeletal organization. 